\title{
39. UN HÍBRIDO NUEVO EN EL GÉNERO ANDRYALA (ASTERACEAE)
}

\author{
Ramón GARCÍA ADÁ
}

Palabras clave: Asteraceae, Andryala, Nothoespecie, España.

En su distribución circunmediterráneo-macaronésica, la Península Ibérica constituye uno de los territorios donde el género Andryala está más diversificado. Los únicos híbridos de los que tenemos noticia, fueron descritos por Maire, del norte de Africa: A. x faurei, [A. arenaria x A. integrifolia] in Bull. Soc. Hist. Nat. Afr. Nord. 17: 121. (1926). [=A. x caballeroi Font Quer, Cavanillesia 7: 83. 1935)], y A. x dichroa [A. integrifolia x A. laxiflora], in Bull. Soc. Hist. Nat. Afr. Nord. 28: 364. (1937), ambos originados a partir de especies anuales o bianuales, por lo general. El descubierto por nosotros en tierras segovianas es el primero que se detecta en la Península, y donde uno de los parentales, además es claramente perenne.

Andryala x brievaensis García Adá, nothosp. nov.

A. integrifolia L. x A. ragusina $\mathrm{L}$.

Diagnosis: Planta perennis, a A. ragusinae habito, foliis angustioribus, indumento et praecipue receptaculi setae cypselis perspicue longioribus differt; a A. integrifoliae caulibus ad bases lignosis, pedunculis et phyllis involucrorum pilis glanduliferis destitutis recedit.

SEGOVIA: Brieva, 30TVL1244, $1040 \mathrm{~m}$, tomillar pedregoso sobre calizas contiguas a terrenos silíceos, 21-VII-1989, leg. R. García Adá y G. López, 6546 RG. Holotypus: MA 503134, Isotypus: MA 503135.
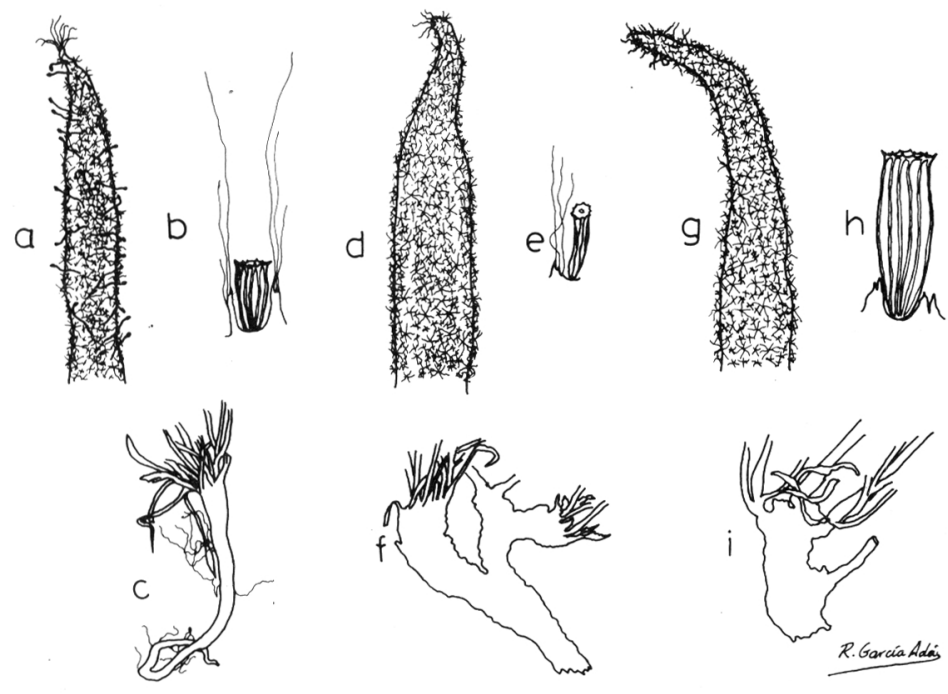

Fig. 1. A.integrifolia: a) Bráctea; b) Detalle del receptáculo; c) Cepa. A. x brievaensis: d) Bráctea; e) Detalle del receptáculo; f) Cepa. A. ragusina: g) Bráctea; h) Detalle del receptáculo; i) Cepa. 
Planta perenne, que difiere de A. ragusina por presentar pelos más largos que las cipselas en el receptáculo y hojas casi siempre más estrechas; de A. integrifolia se distingue por ser leñosa en la base y carecer de pelos glandulares en pedúnculos e involucros. Se halló conviviendo entre los progenitores (MA 503137, MA 503136), sobre un terreno de transición silíceo-calcáreo, donde se asentaban otros táxones característicos de ambos tipos de substrato. Las notables diferencias entre las especies involucradas y los claros caracteres morfológicos del híbrido, hacen que consideremos innecesarios otro tipo de estudios para confirmar su origen. Las cipselas parecen ser vanas.

(Aceptado para su publicación en Mayo de 1992)

Dirección del autor: Real Jardín Botánico, C.S.I.C. Plaza de Murillo, 2. 28014- MADRID. 